\title{
INTERNATIONAL ANTI-CORRUPTION STANDARDS
}

\author{
Vasyl Topchii', Svitlana Zadereiko', \\ Galyna Didkivska ${ }^{3}$, Olesia Bodunova ${ }^{4}$, Dmytro Shevchenko ${ }^{5}$
}

\begin{abstract}
The article studies the issues of combating corruption in the aspect of its incorporation into international standards. Corruption has been identified as a threat to democracy and economic development in many States. It arises from the process of the exchange of power for material assets, that is, when a competent person performs or refrains from performing certain actions for remuneration, and due to the weakness or weakness of state, political and public institutions that control and limit these processes. It was noted that now the world community is seriously thinking about those negative consequences (threat of statehood, undermining trust in the authorities, causing harm to the individual, society, the functioning of organized crime, a drop in the level of professionalism of employees, a decrease in the level of legal awareness of spirituality) caused by corruption, and realized that while measures taken by individual States to combat corruption could have short-term effects, all States needed to act as one in order to achieve serious positive results. It is noted that the international community, in an effort to develop effective measures to prevent and eradicate corruption, has adopted a number of international treaties, as well as recommendations that are not binding, but are used by States as effective mechanisms for monitoring corruption. It was concluded that in recent years much has been done to strengthen anti-corruption legislation in Ukraine and its compliance with international anti-corruption standards. Currently, in the current political environment, knowledge and study of international anti-corruption standards is becoming increasingly relevant for both ordinary citizens and law enforcement.
\end{abstract}

Key words: corruption, countering, international standards, anti-corruption, international legislation.

JEL Classification: K33, K42, D73

\section{Introduction}

In the socio-political and academic literature on international political issues, politicians and scholars are increasingly pointing out that government corruption not only has an international dimension, but is also a serious problem of global politics. The risk of widespread corruption is not objectionable. Corruption is inherent, albeit to varying degrees, in all countries, regardless of their political structure and economic level of development. The particular urgency of the topic lies in the acuteness of the existing problem, its enormous scale, the imprint of corruption in all spheres of society and at all levels of government. The widespread discussion of the problem of corruption and the public resonance caused by high-profile corruption scandals confirm the urgency of its solution, and thus the scientific awareness of all aspects of this problem. This is necessary to modernize the state economy, improve the power and quality of public administration. Countering and preventing corruption is one of the most important tasks not only for each state, but also for the entire global community. It is generally recognized that the fight against corruption affects

Corresponding author:

${ }^{1}$ University of the State Fiscal Service of Ukraine, Ukraine.

E-mail: topchii8233@edu-knu.com

ORCID: https://orcid.org/0000-0002-0904-2018

${ }^{2}$ Kyiv National Economic University named after Vadym Hetman, Ukraine.

E-mail: zadereiko@acu-edu.cc

ORCID: https://orcid.org/0000-0003-2117-0917

${ }^{3}$ University of the State Fiscal Service of Ukraine, Ukraine.

E-mail: didkivska@edu.cn.ua

ORCID: https://orcid.org/0000-0001-8617-0702

${ }^{4}$ University of the State Fiscal Service of Ukraine, Ukraine.

E-mail: bodunova@sci-univ.com

ORCID: https://orcid.org/0000-0002-6205-3904

${ }^{5}$ University of the State Fiscal Service of Ukraine, Ukraine.

E-mail: shevchenko@neu.com.de

ORCID: https://orcid.org/0000-0003-1181-2680 
the interests of almost all states. In today's globalized society, the fight against corruption generates a set of problems that affect all areas of society. Without denying the increasing use of corruption for the purpose of exercising power, it can be noted that the need for international efforts to successfully address these problems is recognized both by scholars and specialists in various fields, as well as by public and state figures in individual countries.

To improve the effectiveness of the fight against corruption in government, it is necessary to develop and implement a consistent anti-corruption policy that will protect society from the negative impact of corruption and protect the rights of man and citizen. In the context of globalization, national anticorruption measures are insufficient. It is no coincidence that UN Secretary-General Ban Ki-moon notes that, for example, billions of dollars are stolen or wasted each year in developing countries - due to bribery and other abuses... The global financial crisis underscores the need for greater regulation. To this end, it is necessary to work together to fight corruption more actively. The global community, concerned about the growing number of corruption crimes around the world, has developed a number of fundamental international instruments to counter and fight corruption. Among them stands out the fundamental "UN Convention against Corruption" (UN, 2003). The need for international organizations and governments to engage and cooperate closely with society in the fight against corruption was manifested in the establishment in 2006 of the UN Convention Against Corruption Coalition (UNCAC), an international network of civil society organizations in support of the UNCAC. From then on, both state and non-state actors began to influence the formation of a single global anti-corruption standard.

The empirical basis of the scientific article was the provisions of legal acts of Ukraine, the provisions of international law, in particular relating to the issue of combating and preventing corruption. During the work on the article was actively used scientific data from modern jurisprudence, science of international relations, world politics and economics. The theoretical basis of this article served as modern scientific developments of domestic and foreign scientists on international anti-corruption standards, directions of improvement of legislation on this issue and law enforcement practice. During the study were used general scientific methods of analysis and synthesis, historical and systematic approach. Political analysis and descriptive and comparative analysis were used extensively. The case-study method was used to assess the role of civil society organizations in international cooperation against corruption, as well as to study the experience of individual states in the fight against corruption.

\section{The problem of corruption within the legislative framework}

Among the challenges facing the global community, the issue of combating corruption today remains particularly problematic. As it acquires new traits, corruption is penetrating all spheres of life, thereby damaging the state. The World Bank estimates that one trillion dollars are wasted annually around the world. Even more dangerous is the close connection between corruption and organized crime. These phenomena, being symbiotic, complement each other, thus increasing the sustainability of their activities. The global community, concerned about the trends of corruption, is trying in every way to counter this phenomenon. In this regard, discussions are taking place in global forums and international standards and mechanisms are being adopted to combat corruption. However, in most cases, the fight against corruption is conducted locally, at the national level, since the process of integration of states on this issue is slow. In addition, among the adopted international instruments, declarative acts outnumber generally binding documents. Problems with the harmonization of legislation on liability for corruption are also a serious obstacle.

Corruption is a threat to democracy and economic development in many states. It arises in the process of exchanging power for material goods, that is, when a competent person performs or refrains from performing certain acts for reward, and because of the weakness or infirmity of the state, political and social institutions that control and limit these processes. In today's world, the issue of combating corruption is very relevant. All states are concerned about this social phenomenon, which serves as a springboard for various types of crime to flourish, which in turn can destabilize society, create many "shadow" economies, and disrupt the normal functioning of state bodies. As a result, it can threaten the existence of the social institution of the state, which is the impetus for the emergence of pockets of anarchy and widespread violations of human rights.

The legal definition of corruption dates back to antiquity. For example, in Roman law, "corrumpere" meant any unlawful act committed against a judge. Machiavelli (1990) believed that corruption was the exploitation of public opportunities for personal gain (Abashidze, 2007). In his work The Prince, he noted: "There is one unmistakable way to find out what an assistant is worth. If he cares more about himself than about the state, and in any way seeks his benefit, he will never be a good minister to the state, and he will never be able to rely on him" (Machiavelli, 1990). Thus, the preamble to the UN Convention against Corruption (United Nations, 2003) notes that "corruption is no longer a local problem, but 
a transnational phenomenon that affects all societies and economies, making international cooperation in preventing and combating corruption extremely important..." In the international legal sense, "corruption is the abuse of public power for personal gain" (United Nations, 2003).

The world community is now thinking seriously about the negative consequences of corruption (threat to statehood, undermining trust in government, harming individuals and society, the functioning of organized crime, a lower level of professionalism among employees, a lower level of legal consciousness and spirituality) and has realized that while measures taken by individual states to combat corruption may have a short-term effect, all states must act as one unit to achieve serious positive results. Corruption exists in every society. What is common to all states is that corruption is condemned in every culture and that most countries have adopted anti-corruption legislation. In an effort to develop effective measures to prevent and eradicate corruption, the international community has adopted a number of international instruments, as well as recommendations that are not binding, but are used by states as effective mechanisms to control corruption.

Recently, however, the international practice of bribing foreign officials has become widespread. In some countries, it was even possible to get a deduction for a bribe from a company's tax liability (Council of Europe, 2015), and not surprisingly, international corporations were paying bribes around the world to secure business. A series of related juicy corruption scandals have changed the situation. For example, during investigations in the mid-seventies, more than 400 U.S. companies admitted that they also bribed foreign government officials, politicians, and political lotions with "gratuities" totaling more than $\$ 300$ million (Council of Europe, 2015). In this context, the U.S. Congress passed the Foreign Corrupt Practices Act (1977), which for the first time made bribery of a foreign official a crime. The adoption of this law prompted greater cooperation among states in discussing corruption problems and the need to develop international standards to combat corruption, both globally and regionally.

For comprehensive study of such phenomenon as corruption, except acts it is necessary to address the theoretical bases stated in works of scientists. According to professor Dolgova (1997), corruption represents "the social phenomenon which is characterized by bribery - bribability of the public or other servants and on this basis mercenary use by them in personal or in the factional, corporate interests of official office powers, related the authority and opportunities." Famous scientist-lawyer, professor Kuznetsova (Gurov et al., 1994) defines corruption as "socially dangerous phenomenon which is expressed in bribery of employees of government and non-state structures". Kirpichnikov (1997) gives the following definition to corruption: "Corruption is a corrosion of the power. As rust corrodes metal, thus corruption destroys government and corrodes the moral background of society". Volzhenkin (1998) gives the most developed definition to corruption. According to him, corruption is the social phenomenon consisting in decomposition of the power when the public (municipal) servants and other persons authorized for performance of the state functions use the official position, the status and authority of a post on the mercenary purposes for personal enrichment or in group interests. The political scientist Nye (1967), defines corruption as "behavior which doesn't correspond to formal duties of a public role, owing to the private relations (personal, family) used for enrichment or increase in the social status".

It cannot be said that corruption is always illegal, because it can exist within the legal framework. Thus, corruption now includes not only illicit gain and embezzlement, but also other options that are legal in many countries. For example, the concept of "lobbyism," which exists in the United States and consists of sponsoring politicians, public organizations and the press to perform actions that benefit a certain group of people. According to the philosophical encyclopedia, "lobbyism" (from the English lobby lobby, corridor, foyer) is a rendering pressure upon public authorities from social and political groups, the commercial organizations or individuals for the purpose of adoption of acts favorable by him, administrative or political decisions" (Stiopin, 2000). At the same time a legislative basis for this activity is the first amendment to the Constitution of the USA (1787) affirming the right for freedom of speech and a possibility of the appeal to the Congress. According to official figures, annually in Washington as lobbyists is registered from about 10,000 people (Lobby It, 2021).

Although corruption is perceived negatively from the legal point of view, from the economic point of view many authors justify the manifestation of corruption. Theobald (1990), derived such benefits of corruption:

- accumulation of the capital;

- enterprise;

- penetration of business approach on bureaucratic Wednesday;

- influence of market forces.

Timofeev (2000) considers that "in many cases the corruption will be considered as the phenomenon positive, reasonable as manifestation of common sense in economic behavior of the person. It turns out that quite so it becomes visible if to address a historical retrospective. Time washes away a soot 
of legal prejudices and ideological myths from the historical phenomena and allows to make out deep motive of public conduct of the person - his rational economic interest which explains, and sometimes and justifies crime of the legal law". Levin and Satarov (1997) see corruption as a "lubricant" that can compensate for weaknesses in public administration. While these conclusions may seem fair at first glance, they are incorrect because they do not take into account the negative effects of corruption. Based on the above, it is reasonable to say that corruption is a form of dishonest as well as unethical behavior of a person who is entrusted with some rights to represent the government at any given level, in order to exercise the functions of government aimed at gaining personal benefit.

\section{Global corruption indicators}

The need to combat corruption is recognized by government institutions, businesses, and civil society organizations around the world. The specifics of this problem, the theoretical and practical difficulty of combating it lies in the lack of a single criterion for assessing corruption and generally accepted methods of measuring its level in a particular state. Also, for obvious reasons, the level of corruption in a country cannot be objectively assessed by collecting only empirical data. In order to improve the effectiveness of anti-corruption measures at the national and, especially, international levels, it is necessary to be able to distinguish corruption and understand the extent of its impact on the state and society. But how does one know which countries have excessively high levels of corruption, and where corruption is extremely rare?

The most commonly used measure of a state's level of corruption is the Corruption Perceptions Index, introduced by Transparency International. First launched in 1995 as a unique and innovative project, the Corruption Perceptions Index quickly attracted major media attention, which in turn increased public interest in the problem and even led states to compete in trying to improve their performance. The index was based on a ten-point scale of assessments by independent international finance and human rights experts (since 2012, it has been based on a hundred-point scale). The score is higher - the level of corruption is lower. But this approach has several drawbacks: first, there are notoriously no absolutely independent experts - this affects the objectivity of assessments; and second, due to the growing popularity of Transparency International, the Corruption Perception Index is increasingly influenced by perceptions. The situation described in works "Corruption and the government: causes, consequences and reforms", "When everyone considers that all wallowed in corruption, unless the Saint will refrain from bribery" (Rose-Ackerman, 1999).

Public opinion becomes tolerant of corruption, initially at the domestic level, and then to political corruption. Third, national perceptions of corruption should not be ignored; the same action may be considered a tradition or a norm of behavior in one state and a corruption offense in another. Fourth, using this ranking, it is sometimes difficult to track the dynamics of the fight against corruption around the world; states both leading and lagging in this ranking rarely change their positions fundamentally. It is also no longer a question of any precise quantitative measurements of corrupt practices. In 1999, TI compiled the Bribe Payers Index, which is a ranking of the most economically developed countries according to the prevalence of corrupt practices in the activities of companies in these countries. Thus, the citizens of any state have the opportunity to get acquainted with the countries involved in the "export of corruption". On the one hand, this indicator may partially reflect the level of corruption in the state, loyalty to corrupt officials or the desire to fight them by the business of a particular state; on the other hand, international business has its own specifics, data on corrupt deals abroad may distort the real picture of the level of corruption in the state.

Since 2003, TI has been conducting a study called the Global Corruption Barometer, which is a sociological survey of citizens from various countries about their experiences with corrupt acts. The objectives of this project are to look at corruption by sector; to identify the most corrupt government agencies; to assess the effectiveness of government anti-corruption efforts, etc. Its undoubted advantages are a broad empirical base of data on manifestations of corruption; the possibility of analyzing government efforts to combat corruption; a study of these phenomena in dynamics. However, the Barometer data does not always correspond to the Corruption Perceptions Index, and the questions of the sociological survey change the compilers in an attempt to achieve maximum objectivity in assessing the level of corruption from year to year.

In addition to corruption studies conducted by Transparency International, there are many other indicators of corruption in a state. The research "Quality of Public Administration" created in 1996 by experts of the World Bank Kauffman, Kraayem and Mastruzzi is represented very productive and important for the solution of objectives of this research. "The quality of public administration" is the rating of efficiency of public administration consisting of six indicators: accounting of opinion of the population and accountability of public 
authorities, political stability and lack of violence, overall performance of the government, quality of the legislation, rule of law, corruption control. It is noteworthy that in most countries with low indicators of corruption control, other indicators of the quality of public administration are also low. Researchers Kaufmann, Kraay and Zoydo-Lobaton conducted a series of the international surveys (with participation of the World Bank, International Country Risk Guide, etc.). Participants of polls were divided into two groups: businessmen and ordinary citizens of the country, and group of experts. Advantages of the $\mathrm{KKZ}$ index is the broad coverage of the countries in which surveys, and a variety of the sources used at them were conducted. One of shortcomings of this method - too wide range of questions and also their heterogeneity at various polls.

The most various indicators of corruption (indicators by which it is possible to determine corruption level in the state) are considered in article "Political institutes and corruption: role of the unitary state and territorial device and parliamentarism" (Gerring et al., 2004): GDP per capita; restrictions for capital flow; negative impact on investments and so forth. Young researchers recognize that the main problem in measuring the level of corruption in a state or region is the large number of indicators by which it is measured. Undoubtedly, in order to increase the effectiveness of international cooperation in combating corruption in government, it is necessary to establish more accurate criteria for determining the level of corruption than those that exist today. It is to this end that a number of the following activities are proposed:

1) to analyze the causes and distribution of corruption in the concrete country, to track a historical way of this phenomenon in specific conditions;

2) to define what is the maximum allowed level of corruption and whether everywhere it will be identical;

3) to study the available national successful experience of fight against corruption, also to consider failures of the states on this way;

4) to investigate the international documents directed to fight against corruption, to estimate their efficiency at the moment;

5) to compare the 3 and 4 points to consider the possibility of application of experience of the country's most of which of all succeeded in fight against corruption and creation of the international standards which can be implemented to the countries with the high level of corruption (considering their specifics, to carry out so-called "benchmarking" of anticorruption);

6) to create the anti-corruption programs combining "carrot and stick" - from democratization of all spheres of life, economic and political freedoms, creation of an active civic stand at the population and, as a result, formation of civil society, conducting scheduled and explanatory maintenance about harm and inadmissibility of corruption before strengthening of selection of shots at a position of public service, inevitability of punishment for an assistance;

7) to increase quality of anti-corruption examination of normative legal acts, to introduce the system of assessment of the regulating influence of bills at the state and local levels of public administration.

Corruption measurement methods, important for this research, are given in work of "Corruption around the world" (Tanzi, 1998). The hypothesis that there are no direct methods of measuring corruption is interesting. "There are no direct ways to measure corruption yet, but there are indirect ways to get information about its prevalence in a state or a public authority" (Tanzi, 1998). This information, according to the famous economist Tanzi (1998), can be found:

1 ) in the reports on corruption available in the published sources, including newspapers. The Internet becomes more and more valuable source;

2) concerning cases of the corruption crimes investigated at such often state institutes which face corruption as tax administration, customs, police and some other;

3 ) in studies from the survey.

\section{International experience in combating corruption}

A number of studies that cite the monetary amount of a bribe as an indicator of corruption cannot be fully considered as such, since corruption is not only manifested in bribes (appointing relatives to positions, etc.). Moreover, it is not always possible to accurately measure bribes in monetary terms (vacation pay; payment for medical treatment abroad, etc.). In the work "Corruption - the world's big c: cases, causes, consequences, cures" (Senior, 2006) are given several cases, to give definition which as "corruption crime" or "lack of structure of corruption crime" is quite difficult. The author tries to understand and explain why one is corrupt and the other is not. But here, too, the answers are not obvious.

From this it can be concluded that the same event can be viewed differently in different countries: in one country it will be an act of corruption, in another - not. From this it can be concluded that the perception of corruption is conditional, and its assessment by citizens is often subjective. An interesting way to measure the level of corruption in the state could be an assessment of the effectiveness of a particular public service, for example, the registration of legal entities. This assessment could include the time spent waiting for the provision of a service, its cost, as well as the availability of options 
for obtaining a service through corrupt practices, their number and cost. Of course, it is impossible to determine the level of corruption in a country by one criterion, but the number of indicators could be reasonably increased with a careful development of the evaluation methodology. The paper considers that the most appropriate is the conventional division of all states into:

1) those which fight against corruption and recognize her harm for economic, political and social development of the country;

2) those who do not consider corruption in government to be a serious problem.

It is possible to distinguish between successful and unsuccessful anti-corruption states, or not at all. It is difficult to distinguish between "successful" and "unsuccessful" states in the fight against corruption. The key question here is what counts as success? The answer is not straightforward. Perhaps "successful" in the fight against corruption can be considered that state, where the predominance of personal interest over public interest of officials in the exercise of power is illegal, it is systematically fought, all conditions for the fight are created, the concrete results of anti-corruption fight are visible.

It is obvious that complete eradication of corruption in the state is impossible. Therefore, it is a certain abstract ideal - a state with an established system of counteraction and fight against corruption, the transparency of which is confirmed by public control and active international cooperation in this direction; and officials have no incentives to engage in corrupt acts. Closeness to it (which in this case is a strong factor for the successful fight against corruption) can be achieved when the fight is conducted in a comprehensive way, on all fronts. This requires a political will against corruption in the state; developed anti-corruption legislation, its practical application; participation in international cooperation in the fight against corruption, accession to major international anti-corruption documents; a properly built system of selection of civil servants, the presence of incentives for them not to engage in corrupt practices; the development of civil society institutions, their participation in monitoring the activities of the authorities; the openness of the government, its accountability; the turnover of power, the democratic nature of the electoral system and some other indicators.

Each state has a relation to the fight against corruption, independently adopting measures, which it is guided by in this fight. In this paper we propose to consider the most effective anti-corruption international standards (programs), the borrowing of which would be useful both for the international community as a whole, and for Ukraine in particular. Analysis of the fight against corruption in states that have not yet achieved great success in this area is also important for solving the tasks of our study: their experience can warn other states and the entire international community against committing the mistakes already made in the anti-corruption fight. The lessons of international experience in combating corruption in the state are especially relevant for our state, which is in search of an effective anti-corruption policy. Considering the Corruption Perceptions Index for previous years, the top twenty least corrupt countries are Denmark, New Zealand, Finland, Sweden, Norway, Singapore, Switzerland, the Netherlands, Australia, Canada, Luxembourg, Germany, Iceland, Great Britain, Barbados, while virtually all of the above countries have been successfully fighting corruption and have been high in the rankings for at least the last decade. Undoubtedly, all states that successfully fight corruption consider this problem as a threat to their security. As a rule, a balanced anti-corruption policy and specialized institutions are created to counteract this pernicious phenomenon.

It is possible to distinguish three models of combating corruption in states that have been successful in combating corruption. The first model is represented in the countries of Northern and Western Europe (it is especially well traced in the Scandinavian countries). The state institutions of Norway, Sweden, Finland, and Denmark are among the best in the world, often combining the principles of a social and constitutional state. Free competition in the economy, a developed civil society, and the high role of the media in combating corruption crimes are the cornerstones of their anti-corruption policies. A characteristic feature of the "Northern European" model of anti-corruption policy can be considered the active role of public authorities in the redistribution of funds in the state with their maximum possible transparency and accountability to the public. One of the reasons why any corruption crime covered in the media immediately becomes a national scandal is undoubtedly the moral approach established in the societies of these states. Due to the high level of trust between people, any corruption offense is perceived sharply negatively, as a manifestation of immoral behavior. The population trusts the state, tax evasion is not considered acceptable in Scandinavian countries, and in addition, every citizen can review the documents received by public institutions.

For example, in Denmark there are about 20 acts which to a degree concern fight against corruption. Parliament of Denmark, public activists, members of the media closely interact and carry out joint monitoring of potential acts of corruption. In Denmark the state gives social guarantees to citizens and carries out them. Citizens trust the government 
and are ready to pay high taxes, knowing that the quality of public services will be by all means high. An important point is the developed corporate social responsibility of the Danish business. The reputation of the company is usually more important for her heads, than short-term success from participation in the corruption transaction. The lack of the separate act on fight against corruption doesn't prevent Finland to counteract this destructive successfully phenomena. A number of the conditions which are consciously realized by the authorities of Finland allows to constrain corruption in the limits which aren't posing threat to social development:

- existence of the developed institutes of civil society, including media;

- aspiration to minimization of intervention of the state in the economic sector;

- transparency and publicity of decision-making process by officials, openness and availability of the majority standard and bylaws;

- political, financial and personnel independence of a justice system of executive power, the valid guarantee of protection of the persons who rendered assistance to competent authorities in fight against corruption; and also other measures directed to bureaucratization reduction, improvement of quality of public administration, creation of a control system for activity of officials at the worthy level of the salary of officials etc. Especially it would be desirable to note work with civil society and creation of the atmospheres of rejection of corruption in all forms society and negative attitude to her among public servants.

Other model of anti-corruption fight is presented in the countries of Southeast Asia, first of all, in Singapore, Hong Kong, Taiwan, Malaysia. Also it is possible to carry South Korea and Japan to this model. Its specifics consist in the verified personnel policy, the greatest possible leaving of the state regulation of economy, creation of special anti-corruption bodies, equality of all before the law, severe punishment for corruption crimes. Singapore's economic success has also been due to the effective fight against corruption and the political will of its leaders. It has established a special anti-corruption body, the Corruption Investigation Bureau, which is fully independent and takes action against corruption and combating it.

Reference can be made to Singapore's leading anticorruption principles: 1) public servants are paid according to a formula tied to the average salary of those successfully employed in the private sector; 2) supervised annual reporting by public officials of their assets, assets and debts; the prosecutor has the right to inspect any bank, share and current accounts of those suspected of violating the Prevention of Corruption Act; 3) greater severity in corruption cases against high-ranking officials to maintain the moral authority of incorruptible political leaders; 4) elimination of excessive administrative barriers to economic development. Thus, it can be noted that anti-corruption policy is formed on the creation of a system of state control, in which officials have almost no need to commit inducements of corruption crimes. At the same time, the principle of public control over the actions of officials, as well as the principle of equality before the law and the inevitability of punishment for the crime committed in Singapore.

The Republic of Korea attaches great importance to involving citizens in the fight against corruption. In 1999, the OPEN program was established in Seoul. It is an online system for citizens to report corruption. Any report submitted must be investigated. Citizens are given security guarantees when they participate in the fight against corruption. Communication with officials is kept to a minimum, and the progress of the application is displayed in the citizen's personal Internet cabinet. The creation of the program has significantly increased the effectiveness of the fight against corruption in the Republic of Korea, increased public confidence in the Seoul administration, and made the administration's activities open and public. In Japan, the core of anti-corruption policy is a welldeveloped personnel policy and a strict system for regulating the activities of officials. At the level of high salaries, the behavior of officials is regulated by the law "National Public Service Ethics" (National Personnel Authority of Japan, 1999). The dual system of incentives (material and moral) with harsh penalties for non-compliance with laws and regulations demonstrates the effectiveness of Japan's fight against government corruption.

The "American model" of anti-corruption efforts (the United States, Canada, and partly Australia) is characterized by a combination of strict, restrictive laws and a system of incentives and rewards that discourage corruption. The U.S. anti-corruption legislation is systemic in nature. It consists of legal acts regulating lobbying, banking, stock exchange and other activities. Although this is not a guarantee that corruption has been completely eliminated, the level of corruption in the US is much lower than in other countries. The fight against corruption is made easier by the fact that in the U.S. there are virtually no immunities for officials. Any official, including the President, congressmen and senators, may be sued, albeit in a special manner, upon release from office. It is also worth noting that the United States of America attempts to prevent acts of corruption in the exercise of power by preventing corruption based on the operation of standards of honor codes for public officials. In general, I would like to emphasize that all countries that successfully fight corruption use the widest range of means and methods, including always 
close cooperation with civil society structures, based on a system of law thinking, openness and accountability of the authorities. Nevertheless, the examples of anti-corruption strategies in the United States, Europe and East Asia show that no state has eradicated corruption completely.

\section{Legal measures to combat corruption}

Today, a number of international documents on fighting corruption have been adopted within the framework of various international organizations, which emphasizes the importance of the problem and the fact that the fight against corruption is a problem of all states in the world. These are such international contracts as: 1) the Inter-American anticorruption convention adopted by the Organization of American States (1996) came into force in 1997; 2 ) the Convention against corruption involving public officials of the European communities or officials of Member States of the European Union (Council of the European Union, 1997); 3) the Convention on combating bribery of foreign public officials in international business transactions (Organization for Economic Cooperation and Development, 1997), came into force in $1999 ; 4)$ the Convention of the Council of Europe (1999b) on criminal liability for corruption, came into force of 2002 ; 5) the Convention of the Council of Europe (1999a) on civil responsibility for corruption, came into force in 2003; 6) the Convention of the United Nations (2003) against corruption, came into force in 2005; 7) the Convention of the African Union (2003) on preventing and combating corruption, came into force in 2006; 8) the Anti-corruption convention of League of Arab States (2010), didn't come into force yet.

Among the above-mentioned international treaties on combating corruption is the UN Convention against Corruption (2003), a universal international treaty uniting 172 states. The day of opening for signature of the Convention - December 9 - since 2004 is celebrated as International Anti-Corruption Day. This Convention defines the criminalization of acts of corruption, provides for measures to prevent corruption in the public and private sectors, to establish international cooperation in this area and to recover assets, as well as technical assistance, exchange of information, implementation mechanism and monitoring of its implementation. Ukraine ratified the UN Convention of against corruption by the Law of Ukraine No. 251-V (Verkhovna Rada of Ukraine, 2006). The issue of implementation of Article 20 of the UN Convention against Corruption (UN, 2003) on illicit enrichment is difficult for many states, as it is for Ukraine. This article was not included in the list of what Ukraine has jurisdiction over and is obliged to enforce. According to this article "subject to the constitution and the fundamental principles of the legal system, each State Party shall consider adopting such legislative and other measures as may be necessary to establish the crime as intentional illicit enrichment, that is, a significant increase in the assets of a public official which exceeds his lawful income and which he cannot rationally prove" (UN, 2003).

The specified situation can conflict to the constitutional principle of a presumption of innocence and the right of defendants not to testify against itself and also the husband (wife) and other close relatives. Nevertheless, Ukraine seeks to improve the legislation in this sphere. Various options of improvement of forms of declaring not only the income, but also expenses of officials are studied. So, the Resolution of the Cabinet of Ministers of Ukraine (2006) No. 1673 "On a state of the financial and budgetary discipline, measures to strengthen the fight against corruption and control over the use of the state property and financial resources" lays the legal foundations of control of shortcomings and violations of the financial and budgetary discipline and also the mechanism of prosecution of persons who are found guilty of their assumption.

The duty of declaring of expenses is established in many countries. Need of such declaring is fixed at the legislative and subordinate levels by acts of parliament, public service, taxes, financial control, codes of behavior for various categories of officials, the legislation on fight against corruption. Similar acts work in the USA, Great Britain, Belgium, Italy, Finland, Canada, Australia, China and other states. Ukraine also joined the Convention on fight against bribery of officials of the foreign states in case of carrying out the international business operations of the Organization for Economic Cooperation and Development (1997). This Convention was ratified by the Law of Ukraine No. 998-154 (Verkhovna Rada of Ukraine, 1997). Ukraine is a participant of the Criminal Convention of the Council of Europe on the fight against corruption (1999b), ratified in 2006 by Law of Ukraine No. 252-V (Verkhovna Rada of Ukraine, 1999). Ukraine also takes part in the Civil Convention of the Council of Europe on fight against corruption (1999a). The Convention is directed to protection of persons who suffered losses owing to acts of corruption, including a possibility of indemnification. Besides, this Convention is, perhaps, the only international document which gives definition to corruption. Article 2 of the Convention (1999a) states: "Corruption means direct or indirect extortion, offers, giving or taking of a bribe or any other illegal benefit or a possibility of her receiving which break appropriate performance of any duty 
by the person getting bribes, illegal benefit or an opportunity to have such benefit, or behavior of such person". Ratification by Ukraine of the Civil Convention of the Council of Europe on fight against corruption of 1999, certainly, promotes strengthening of anti-corruption standards (Verkhovna Rada of Ukraine, 2005).

Implementation of rules of international law in the sphere of fight against corruption is an important component of formation of a global anti-corruption order and also a necessary condition of effective fight against corruption at the national level. The analysis shows that practically of all states fragmentation of the implemented provisions of the international acts, their selective character is inherent in the legislation that considerably reduces success of the right of realization (Khabrieva, 2012). Summing up the result above of stated, it should be noted that in recent years a lot of things are made for strengthening of the anti-corruption legislation in Ukraine and its compliances to the international standards on fight against corruption. Now in the existing political situation knowledge and studying the international standards of fight against corruption becomes more and more relevant both for ordinary citizens, and for law enforcement officials.

\section{Conclusion}

So, in the scientific article international anticorruption standards were investigated and on the basis of this research in the conclusion there is an opportunity to develop some practical recommendations to improve the quality of anti-corruption fight for Ukraine:

1) with the interaction of the scientific community, state structures, business and representatives of civil society it seems advisable to create an expert group dealing with the identification of corrupt practices, their measurement and classification. This event would allow not only to fight corruption on the state level more effectively, but also to demonstrate the active position of Ukraine in the world anticorruption fight and spread of the global anticorruption standard of behavior;

2) the initiative to create an international body under the UN that would specialize in combating and countering corruption is useful. Such an initiative for Ukraine would give an opportunity to strengthen the international position in the global anticorruption movement, which, in turn, would have a positive impact on improving Ukraine's international standing and competitiveness on the world stage.

\section{References:}

Abashidze, A. Kh. (2007). Nacionalnye i mezhdunarodnye mery v borbe protiv korrupcii [National and international measures in the fight against corruption]. International Lawyer, no. 2, pp. 26-28. (in Russian)

African Union (2003). African Union Convention on Preventing and Combating Corruption. Available at: https://au.int/sites/default/files/treaties/36382-treaty-0028_-_african_union_convention_on_preventing_ and_combating_corruption_e.pdf

Cabinet of Ministers of Ukraine (2006). Resolution No. 1673 "On the state of financial and budgetary discipline, measures to strengthen the fight against corruption and control over the use of the state property and financial resources". Available at: https://zakon.rada.gov.ua/laws/show/1673-2006-\%D0\%BF\#Text

US Congress (1977). Foreign corrupt practices act. Available at: https://www.justice.gov/criminal-fraud/foreigncorrupt-practices-act

Constitution of the USA (1787). Available at: https://www.senate.gov/civics/constitution_item/constitution.htm

Council of Europe (1999a). Civil law convention on corruption. Available at: https://rm.coe.int/168007f3f6

Council of Europe (1999b). Criminal law convention on corruption. Available at: https://www.coe.int/en/web/ conventions/full-list?module=treaty-detail\&treatynum $=173$

Council of Europe (2015). Basic concepts of anti-corruption activities. A training manual. Available at: https://rm.coe.int/basic-anti-corruption-concepts-a-training-manual/16806eed9d

Council of the European Union (1997). Convention against corruption involving public officials of the European Communities or officials of Member States of the European Union. Available at: https://eur-lex.europa.eu/legalcontent/EN/TXT/?uri=LEGISSUM\%3Al33027

Dolgova, A. I. (1997). Krimilogiya [Criminology]. Moscow: Yurist. (in Russian)

Gerring, J., \& Thacker, S. C. (2004). Political institutions and corruption: the role of unitarism and parliamentarism. British Journal of Political Science, no. 34(2), pp. 295-330.

Gurov, A. I., Kozlov, Yu. G., Kuznetsova, N. F., Minkovski, G. M., \& Pobegailo, E. F. (1994). Krimilogiya [Criminology]. Moscow: Lomonosov Moscow State University. (in Russian)

Khabrieva, T. Ya. (2012). Korrupciya i pravo: doktrinalnye podkhody $k$ postanovke problem [Corruption and law: doctrinal approaches to the problem]. Journal of Russian law, no. 6, pp. 5-17. (in Russian)

Kirpichnikov, O. I. (1997). Vzyatka i korrupciya v Rossii [Bribery and corruption in Russia]. Sankt Peterburg: Alfa. (in Russian)

League of Arab states (2010). Arab anti-corruption convention. Available at: https://star.worldbank.org/sites/ star/files/Arab-Convention-Against-Corruption.pdf 
Levin, M., \& Satarov, G. (1997) Yavlenie korrupcii v Rossii. Pobedit ehto zlo slozhno, no borotsya s nim mozhno [The phenomenon of corruption. It is difficult to defeat this evil, but it can be fought]. The Independent Newspaper, no. 185, pp. 5-6. (in Russian)

Lobby It (2021). Frequently Asked Questions. Available at: https://lobbyit.com/lobbying-faq/

Machiavelli, N. (1990). Gosudar [The Prince]. Moscow: Planeta. (in Russian)

National Personnel Authority of Japan (1999). National public service ethics law. Available at: https://www.ocsc.go.th/sites/default/files/attachment/article/japan_outline_of_the_nation_oublice_service_ ethics law.pdf

Nye, J. S. (1967). Corruption and political development: a cost-benefit analysis. American Political Science Review, no. 61(2), pp. 417-427.

Organization for Economic Cooperation and Development (1997). Convention on combating bribery of foreign public officials in international business transactions. Available at: https://www.oecd.org/daf/antibribery/ConvCombatBribery_ENG.pdf

Organization of American States (1996). The anti-corruption convention. Available at: https://1997-2001.state.gov/ regions/wha/fs_oas_convention.html

Rose-Ackerman, S. (1999). Corruption and the government: causes, consequences, reforms. Cambridge: Cambridge University Press.

Senior, I. (2006). Corruption - the world's big C: cases, causes, consequences, cures. London: Institute of Economic Affairs.

Stiopin, V. S., Guseinov, A. A., Semigin, G. Yu., \& Ogurtsov, A. P. (2000). Novaya filosofskaya ehnciklopediya [New philosophical encyclopedia]. Moscow: Mysl. (in Russian)

Tanzi, V. (1998). Corruption Around the World: Causes, Consequences, Scope and Cures. IMF Working Paper.

Theobald, R. (1990). Corruption, development and underdevelopment. London: Macmillan.

Timofeev, L. M. (2000). Institucionalnaya korrupciya [Institutional corruption]. Moscow: Russian State University for the Humanities. (in Russian)

United Nations (2003). Convention against corruption. Available at: https://www.unodc.org/documents/ brussels/UN_Convention_Against_Corruption.pdf

Verkhovna Rada of Ukraine (1997). Law of Ukraine No. 998-154 "On the ratification of Convention on combating bribery of foreign public officials in international business transactions". Available at: https://zakon.rada.gov.ua/ laws/show/998_154\#Text

Verkhovna Rada of Ukraine (1999). Law of Ukraine No. 252-V "On the ratification of Criminal law convention on corruption". Available at: https://zakon.rada.gov.ua/laws/show/252-16\#Text

Verkhovna Rada of Ukraine (2005). Law of Ukraine No. 2476-IV "On the ratification of Civil law convention on corruption". Available at: https://zakon.rada.gov.ua/laws/show/2476-15\#Text

Verkhovna Rada of Ukraine (2006). Law of Ukraine No. 251-V "On the ratification of the convention of the United Nations against corruption". Available at: https://zakon.rada.gov.ua/laws/show/251-16\#Text

Volzhenkin, B. V. (1998). Korrupciya (Sovremennye standarty v ugolovnom prave i ugolovnom processe) [Corruption (Modern standards in criminal law and in criminal proceeding)]. Sankt Peterburg: Law Institute. (in Russian) 